\title{
TFPT wt Allele
}

National Cancer Institute

\section{Source}

National Cancer Institute. TFPT wt Allele. NCI Thesaurus. Code C97838.

Human TFPT wild-type allele is located in the vicinity of $19 q 13$ and is approximately $9 \mathrm{~kb}$ in length. This allele, which encodes TCF3 fusion partner protein, is involved in the positive regulation of apoptosis. A chromosomal inversion inv(19)(p13;q13) of this gene and the TCF3 gene is associated with pre-B-cell acute lymphoblastic leukemia. 